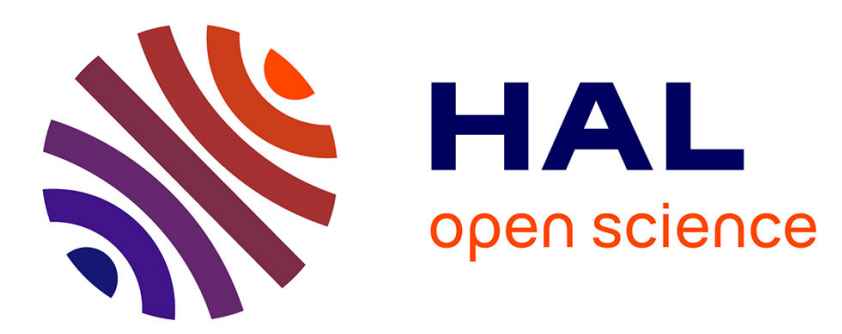

\title{
Indians, Ethiopians and Nubians in western pilgrimage narratives: mere observation or construction of otherness?
}

Camille Rouxpetel

\section{- To cite this version:}

Camille Rouxpetel. Indians, Ethiopians and Nubians in western pilgrimage narratives: mere observation or construction of otherness?. Annales d'Éthiopie, 2012, 27 (1), pp.313 - 317. 10.3406/ethio.2012.1471 . halshs-01618728

\section{HAL Id: halshs-01618728 \\ https://shs.hal.science/halshs-01618728}

Submitted on 21 Nov 2018

HAL is a multi-disciplinary open access archive for the deposit and dissemination of scientific research documents, whether they are published or not. The documents may come from teaching and research institutions in France or abroad, or from public or private research centers.
L'archive ouverte pluridisciplinaire HAL, est destinée au dépôt et à la diffusion de documents scientifiques de niveau recherche, publiés ou non, émanant des établissements d'enseignement et de recherche français ou étrangers, des laboratoires publics ou privés. 


\section{Indians, Ethiopians and Nubians in western pilgrimage} narratives: mere observation or construction of otherness?

Camille Rouxpetel

\section{Citer ce document / Cite this document :}

Rouxpetel Camille. Indians, Ethiopians and Nubians in western pilgrimage narratives: mere observation or construction of otherness?. In: Annales d'Ethiopie. Volume 27, année 2012. pp. 313-317;

doi : 10.3406/ethio.2012.1471

http://www.persee.fr/doc/ethio_0066-2127_2012_num_27_1_1471

Document généré le 08/03/2018 


\title{
Indians, Ethiopians and Nubians in western pilgrimage narratives: mere observation or the construction of otherness?
}

\author{
Camille Rouxpetel*
}

With the development of pilgrimages to the Holy Land following the crusades and the creation of the Crusader States, Roman rite Christians were in contact with Greek and oriental rite Christians, among whom were the Ethiopian, Nubian and Indian people, considered as one single group. Pilgrims got to know these other Christians from various sources - from ancient Latin and Greek authors, from the writings of the Fathers of the Church, from medieval encyclopædias and collections of legends, and also from what they discovered when they met them in flesh and blood in their own environment. These Christians were so far from each other, both geographically and culturally speaking, and the sources were so scattered, that much confusion arose, which needs to be identified and explained. The confusion first came from the ethnonyms used to designate these groups, but also from the way they were ethically and religiously characterized, a process that reflected the different points of view of the various authors of pilgrimage narratives, who described them in a mere questioning perspective but also sometimes in a more controversial one.

Latin authors of pilgrimage narratives used ethnonyms inherited from the learned tradition and derived from the terms India, Ethiopia and Nubia, but also ethnonyms based on the Arabic word al-babaša. The former were the most widely used. In the late $12^{\text {th }}$ century, John of Wurzburg and Theodoric (1172) ${ }^{1}$ were the first pilgrims who respectively mentioned $I n d \imath^{2}$ and Nubian ${ }^{3}$ among the Christians who lived in Jerusalem. In the $13^{\text {th }}$ century, two writers, Oliver von Paderborn (1217-1219) and Burchard of Mount Sion (1274-1283), mentioned Christians who came from India, Nubia and Ethiopia. It was only in the $14^{\text {th }}$ century that they were more frequently mentioned, in narratives written in Latin ${ }^{4}$ or in vernacular

\footnotetext{
* Jeux et enjeux des pouvoirs, Ve-XVe siècles (UMR 8596, Université Paris-Sorbonne, CNRS).

1 Dates in parentheses indicate the date alleged or proven their stay in the Holy Land.

2 Huygens, $1993: 137$.

3 Ibid. : 151.

4 Symon Semeonis, Guillaume de Boldensele, John of Verona, Ludolph von Sudheim et Nicolas de Martoni.
} 


\section{Short versions}

languages ${ }^{5}$. At the beginning of the $13^{\text {th }}$ century, other ethnonyms appeared, in the wake of the fifth crusade. Thietmar, who took part in the fifth crusade, mentioned the Yssint among the Christians he met in Alexandria. He described them with terms usually associated to Ethiopians, but without establishing any equivalence between Yssini and Ethiopians, whether out of ignorance or on purpose. If it were on purpose, it would mean that Theitmar's knowledge of Ethiopians was based only on his personal experience and not on auctoritates. Ludolph von Sudheim (1336-1341) took up the term again with a slight change in the spelling - Ysini. He used the term as a synonym for Nestorian and thus seemed not to be aware of the origin and the meaning of the term he directly borrowed from Thietmar's narrative. John of Verona (1335) used the terms Nubiani and Ethiopes, as well as Jabeni and Abes. He seemed to have difficulty to differentiate between the four groups, for which he also mixed up ancient and contemporary ethnonyms. This may show that he was not aware that they were semantically equivalent.

The fact that these categories of Christians were increasingly mentioned in narratives and writings from the $12^{\text {th }}$ to the $14^{\text {th }}$ centuries shows that they were gradually integrated into western culture. Yet the way they were described and identified was pregnant with confusion, which seems to indicate that western scholars lacked precise elements about them. This lack of precision can be explained by four elements - by ancient conceptions of the geography of India, taken up again by the writers of the patristic period; by the accounts of Alexander's life; by the tradition of the apostolate of Saint Thomas in India; and by the popular myth of Prester John. A tripartite conception of India gradually became indeed dominant - India inferior was thought to be situated south of the Ganges, India superior north of the Ganges, while India ultima designated the regions along the Red $\mathrm{Sea}^{7}$. The conception of a western extension of India may be based on trade, for South Ethiopia and India were linked by a direct maritime trade route ${ }^{8}$. The regions located between the Nile and China thus belonged to India, which occupied the major part of the Orient. As for the tradition of Alexander the Great's Indian saga, it was based on Alexander's romance by Pseudo-Callisthenes, while the story of the apostolate of Saint Thomas in India was popularized in Europe by medieval collections of legends and, from the $12^{\text {th }}$ century on, associated with the narration of posthumous miracles that were attributed to him ${ }^{9}$. The kingdom of Prester John was sometimes believed to be located in India, sometimes believed to be located in Ethiopia ${ }^{10}$. He was a legendary and providential king for the Romans who lived in the Holy Land and were fighting against the Muslim armies.

Confusion between Indians, Ethiopians and Nubians resulted from attempts at distinguishing between the three groups, from attempts at presenting them as a

5 Niccolò da Poggibonsi (1346) et Jean de Mandeville whom story dates from 1356. The reality of the pilgrimage of the latter is discussed. He certainly has not visited the areas to the east of Syria.

6 Laurent, $1873: 54$.

Schneider, $2004: 23-35$.

8 Dihle, 1984 : 90-94 ; Pirenne, 1970 ; Schneider, 2004 : 474-481.

9 Devos, $1948: 231-275$.

10 Baum, 1999 : 123-126 ; Marinescu, 1945 ; et Richard, 1957. 
whole, and more frequently from information transferred from one group to another. For example, Ludolph von Sudheim tried to make a distinction between Nubiani, Indi and Ysini, but attributed to Indians baptismal rites traditionally attributed to Ethiopians. As for Niccolo da Poggibonsi (1346), he tried to differentiate between Indians and Ethiopians according to the colour of their skin and their demographic importance. Conversely, some writers mistook them for one another, like Oliver von Paderborn, who described Ethiopia as populated by Nubians. One century later, John of Verona defined Nubians as "black Ethiopians from the kingdom of Prester John"11 and the latter as "the Lord of Nubia and Ethiopia"12. These two uses of the term Ethiopia could be explained by two different meanings the term could have - it could first mean the country of black people, whose inhabitants could thus be Nubians, but it could also designate a sovereign state like Nubia. Finally, the most frequent attitude for the writers of the time was to mistake Indians for Ethiopians and conversely, to endow the latter the traditional features of the former and conversely. Symon Simeonis (1323) geographically mistook India for Ethiopia ${ }^{13}$. John of Verona called Nubians "Saint Thomas' Christians", a term that was rather reserved for Indians, who were thought to have been converted by Saint Thomas. Nicolas de Martoni (1394-1395) detailed his visit to a patriarch in Cairo, in whose home he said he met Indian pilgrims ${ }^{14}$. He was probably referring to Coptic Patriarch Matthew 1st, and the pilgrims he met there were probably Ethiopians, the Church of Ethiopia depending on the Coptic patriarchate of Alexandria. Near the end of the narrative of his meeting with the patriarch, Nicolas de Martoni reported what the latter as well as the Indian pilgrims said about the miracles Saint Thomas accomplished in India. Their version was different from the ones that were then spread in the western world. Saint Thomas was believed to have appointed, on the day of his celebration, a priest in charge of taking care of his sanctuary for one year; the priest died during the course of the year and was replaced with another one, appointed in the same way. The story was mentioned at the beginning of the $13^{\text {th }}$ century in The History of churches and monasteries of Egypt $t^{15}$, attributed to Abû Sâlih, but probably written by Abû alMakarim, and taken up again by the Ethiopian synaxarium. This shows how widespread the legend was in Coptic and Ethiopian circles as early as the beginning of the $13^{\text {th }}$ century. Nicolas de Martoni may thus have learned about it from pilgrims or even from the patriarch himself, as he claimed. According to this hypothesis, his familiarity with the apostolate of Saint Thomas in India could be at the origin of the wrong identification. Another possibility is that he added the story only later, in order to justify his testimony, which was based on a well-known tradition among western readers. In any case, to relate this anecdote, Nicolas combined the literary tradition of hagiography with his experience of a real meeting with probably Ethiopian pilgrims. In addition, the story suggests that Thomas'

\footnotetext{
11 Monneret de Villard, $1950: 30$.

12 Ibid. : p. 31.

13 Esposito, 1960 : chapter 87.

14 Le Grand, 1895 : 33.

15 Evetts, 1895 : 296-299.
} 


\section{Short versions}

Indian apostolate was known in the West and perhaps also shows how an Ethiopian legend could be passed on to a Western, Latin-speaking pilgrim. Nicolas de Martoni tells it without questioning it, probably because he was familiar with the western tradition, but also perhaps because he trusted these Christians and praised their piety. A careful reading of those pilgrims' narratives shows that Ethiopians had a much less negative image than François de Medeiros exposed ${ }^{16}$.

The way Ethiopians were perceived by western pilgrims thus questions the polemical or exotic tone of their writings. The notion of exoticism is defined by Emmanuèle Baumgartner as an attitude of openness to the Other, considered in his human rather than symbolic or mythological dimension, in the context of travel narratives dealing with a weird and distant country ${ }^{17}$. Eastern Christians were frequently, though far from systematically, mentioned by pilgrims, which suggests that they paid attention to their human environment and they were curious about those Christians, whose appearance, rites and beliefs were different from theirs. Among all the authors of pilgrimage narratives evoking Ethiopians and Nubians in the $12^{\text {th }}, 13^{\text {th }}$ and $14^{\text {th }}$ centuries, only a few, namely Symon Semeonis, John of Verona and Niccolò da Poggibonsi, in a very matter-of-fact way mention their skin colour as a distinctive feature. None of them does in a controversial or moral perspective, contrary to some western writers or painters, who depicted demons as Ethiopians because of the colour of their skin, blackness being associated with evil in demonological works ${ }^{18}$. Niccolò da Poggibonsi described the sacrifizio, i.e. Eucharist, practiced by Ethiopians, for its sheer otherness. In the same way, Thietmar's and Ludolph Von Sudheim's narratives described the specificity of their baptism, which became a topos in descriptions of these peoples, as it was both considered an exotic element as well as a token of religious otherness. Observing how those eastern Christians lived was what the authors of pilgrimage narratives were interested in; they wrote little about the mirabilia that tradition attributed to them and that could be found in other works, especially encyclopædias. When they mentioned those mirabilia, they didn't mix up the real Ethiopians that they actually met with the mythical people who lived in the same region or in other, neighbouring regions, as the example of Pugia and Barbaria, mentioned by Ludolph von Sudheim, shows ${ }^{19}$. Authors of pilgrimage narratives were more focused on the alliance that westerners could make with these people in the context of the fifth crusade or on plans for other crusades that blossomed after the fall of Acre in 1291. In this perspective, Thietmar ${ }^{20}$, John of Verona ${ }^{21}$ and Niccolo da Poggibonsi ${ }^{22}$ noted how numerous they were and that they were exempted from paying tribute to the Sultan of Cairo, which suggested how powerful they were - thus confirming the myth of Pester John. They also pointed out elements indicating the hope of a

16 De Medeiros, 1985.

17 Baumgartner, $2003: 13$.

18 De Medeiros, 1985 : 228-233 et Devisse, 1979 : 57-59.

19 Deycks, $1851: 7$.

20 Laurent, $1873: 54$.

21 Monneret de Villard, 1950 : 31.

22 Bacchi della Lega, 1945 : 149. 
possible alliance with Rome. Lastly they wrote about the Christian faith of the Ethiopians, Indians and Nubians, aiming at both showing unity and differences. Nicolas de Martoni was the only one who wrote about their beliefs, the other pilgrims merely describing their rites, especially their baptismal rites, which became a set feature of the image of those Christians. John of Verona and Niccolo da Poggibonsi underlined their differences and, with Nicolas de Martoni, also underlined their piety, which they deduced from their behaviour. Ludolph von Sudheim and Symon Semeonis remarked how close Latin, Ethiopian, Nubian and Indian rites were getting to one another, while making it clear that the eastern rites were schismatic, i.e. they didn't acknowledge the authority of the Pope. Considering Indians, Ethiopians and Nubians as Christians thus meant underlining a common Christian identity but at the same time emphasizing differences between Eastern and Western Christians. One may see in the construction of such a Christian otherness a way of trying to make what is too different and puzzling more familiar, rather than an ecumenical construction or the influence of the Pope's policy of Union of Churches.

Putting Roman and eastern Christians into contact, crusades and pilgrimages contributed to making Westerners familiar with Indians, Ethiopians and Nubians and to renewing their image. The way they were perceived was based on various written sources as well as on their experience, and was rather stable - they were seen as black-skinned, scarified Christians who were pious and powerful. However it is possible to make out slight differences between the various writers depending on their status or intentions. Thietmar, a crusader in the fifth crusade, thus insisted on their military hostility to Saracens, while Burchard, a Black Friar, and John of Verona, an Augustinian monk, were more interested in their Christian identity. John of Verona only referred to Prester John because he was upset with the taxes he had to pay to get into the Church of the Holy Sepulchre. So he reacted as a pilgrim rather than as a crusader. Niccolo da Poggibonsi, a Franciscan monk, was surprised by the Ethiopian liturgy, while Jean de Mandeville, who aimed at "diversetez qe soient par dela", went to great length about mirabilia. The image of those Christians was still rather stable as most of the time the authors of pilgrimage narratives considered them from a realistic point of view, deprived of any controversial judgment, while calling on the legends that were associated with them and were part and parcel of the medieval cultural world picture of the West. 